\title{
NEEDS FOR NEW CADASTRAL SURVEYING BUILDING REGION IN THE TOWN OF BAČKA PALANKA
}

\author{
Dr Miroslav Kuburić* \\ Geoput d.o.o, Belgrade, Serbia \\ Milan Filipović \\ Geoput d.o.o, Belgrade, Serbia \\ Mladen Lero \\ Geoput d.o.o, Belgrade, Serbia
}

In this article is presented the short overwiev on previews works of cadastral measurements on territory of municipality of Bačka Palanka and direct comparison data on cadastral maps with data on new digital ortophoto plans (aerial photography from 2010.) on the building region in the town Bačka Palanka. Base on that there is suggestion to make new measurements on the building region in the town Bačka Palanka using new technology. According to this the analysis is given in the study („Geoput“ 2010.) which gives available cadastral data and their updating, credibility and level of useable this data in the process of making decisions about economize lend and creating adequate plans for using, classification and arrangement trade and other recourses on this part of building region. The study gives information about cadastral measurements in chronological way from 1864, which carried out in harmony with possibilities of local government and according to plans and programs of work of republic establishment. From other side the study gives suggestion of work on the cadastral measurements in the next period according law regulation and possibility of institutions, which dallies, and which are authoritative in this area.

Key words: Cadastral measurements, Previews study of reasonable, Civil region, Municipality Bačka Palanka

\section{INTRODUCTION}

In recent years local government municipality of Bačka Palanka its activity focused on improving the system of management of the land under their jurisdiction. For the realization of these activities, starting point are the cadastre data, which is a basic, and a public registry of immovable property and rights to them, but within this perceived problem of lack state cadastral records in comparison with the facts on the ground. Such a situation has inevitably generated a need to determine the degree of promptness, quality, reliability and usability of data available in order to make quality decisions on the management of the municipal resources. The area of space measurement and its elements for the establishment and renewal of cadastre and monitoring, updating and keeping of cadastre data in its professional and administrative terms, as a work of general interest for the Republic of Serbia, is under the jurisdiction of the Republic Geodetic Authority. This job can be recommended to a geodetic organization, which meted the statutory requirements. In accordance with the applicable laws and regulations covering this area, a private company "GEOPUT" doo from Belgrade, has prepared a feasibility study on the previous performance of the new surveying building region of municipality Bačka Palanka.

\section{GEOGRAPHICAL POSITION TERRITORY OF MUNICIPALITY BAČKA PALANKA}

The territory of Bačka Palanka municipality covers an area of $579 \mathrm{~km}^{2}$, located in the western part of Vojvodina, and together with the municipalities Bač Beočin Bački Petrovac, Vrbas, city Novi Sad, Sremski Karlovci, Srbobran, Temerin, Bečej, and municipality Žabalj and Titel seems 
South Bačka District. For its development of the municipality is located in the top 10 (of 45) in the Province. The southern part of the municipal boundary is located on the river Danube, which is the border with Republic Croatia, and the remaining lower part of the southern land borders of the municipality of Backa Palanka, is over the Danube River, and has the borders with the municipalities of Šid and Sremska Mitrovica of Srem. The Danube river except that the boundary between the states of Serbia and Croatia, it is also the border between Bačka and Srem, while the water flow divided municipality territory in two parts, one northern which is the larger and smaller southern part.

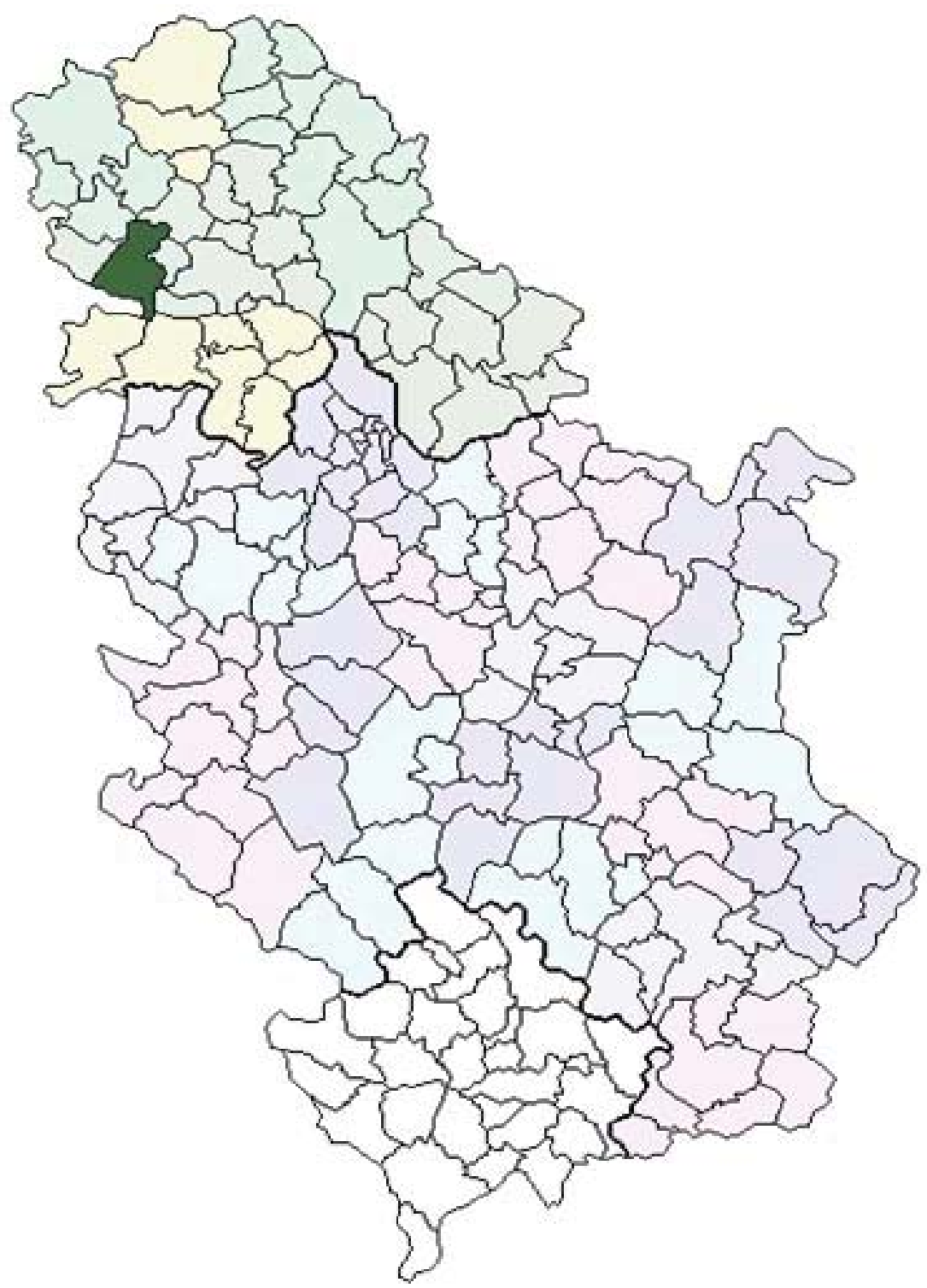

Figure 1: The position of municipality Bačka Palanka in Republic Serbia [03]

It was noted that on the position of current city of Bačka Palanka, the first settlement on this region raised in the eleventh century, and the name Palanka was mentioned from the $1593^{\text {rd }}$ year. At the end of the sixteenth century this area was occupied by the Turks, but after the signing of Karlovac Peace 1699th, Turks departure this territory, after which the area inhabited by Serbian, German, Slovak and Hungarian population. Therefore, here there the Old, New and
Germany Palanka, and later this area became known as Bačka Palanka. During the eighteenth and nineteenth centuries in this area began to develop the economy (production of bricks, tobacco processing of wood, hemp, and lower production of silk), which contributed to the overall development of the area and a substantial settlement. Now the territory of Bačka Palanka municipality has 14 settlements, 12 to the left and 2 (Neštin and Vizić) on the right bank of the Dan- 
ube, where living more than 60 thousand people of different nationality. The territory of Bačka Palanka municipality is divided into 15 cadastral municipalities (CM) with the following names: Bačka Palanka, Bačka Palanka-town, Vizić,
Gajdobra, Despotovo, Mladenovo, Neštin, Nova Gajdobra, Nova Palanka, Obrovac, Parage, Pivnice, Silbaš, Tovariševo and Čelarevo, as can be seen in Figure 2.
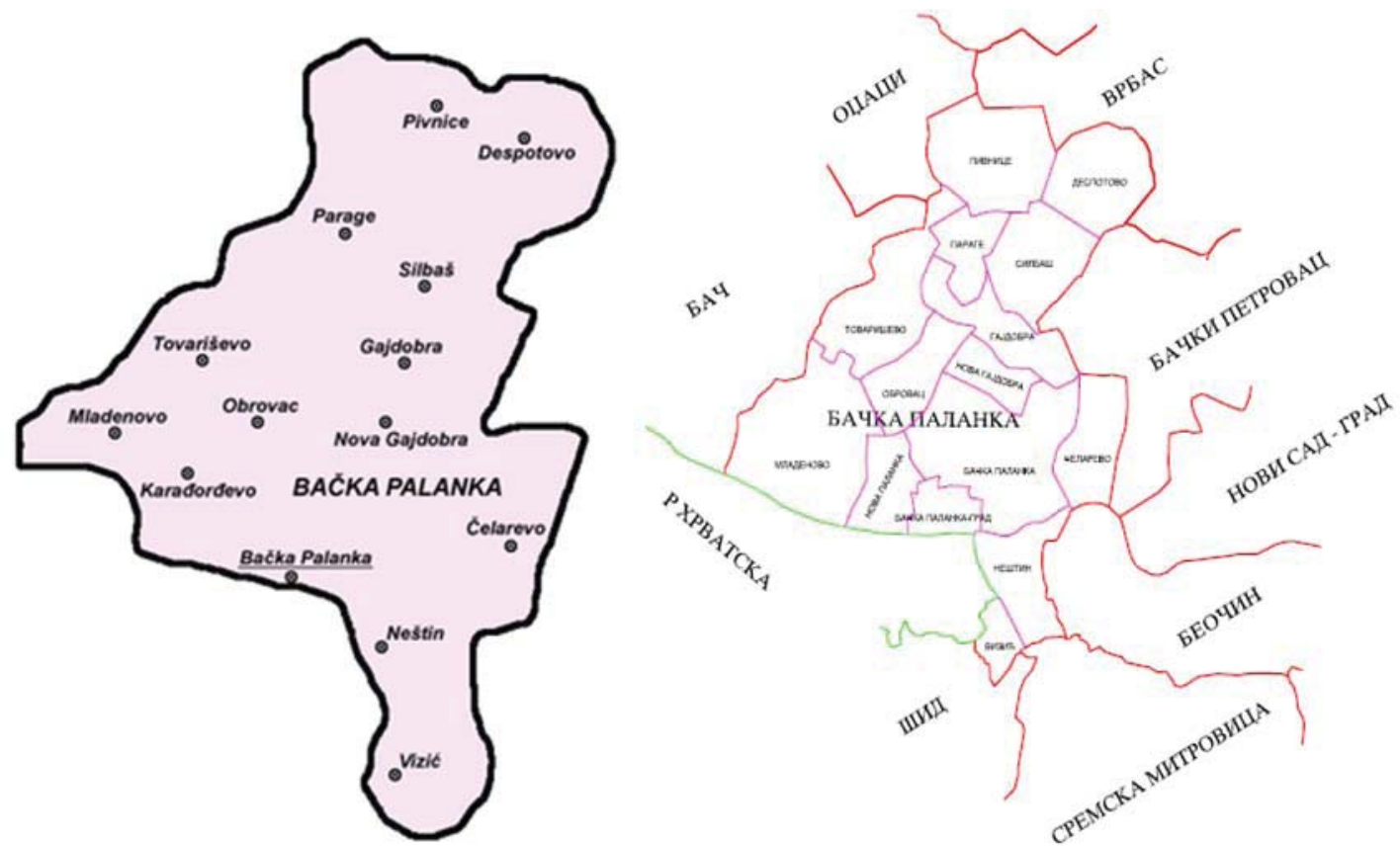

Figure 2: The names of settlements (14) and cadastral municipalities (15) in the Municipality of Bačka Palanka [02]

\section{ESTABLISHING AND MAINTAINING CADASTRAL SURVEYING IN MUNICIPALITY OF BAČKA PALANKA}

Cadastral surveying and cadastral renewal survey on the cadastral municipalities on the territory of Bačka Palanka was carried out at different times and using different methods surveying of details (aerial survey, application consolidation, application of polar and orthogonal method of surveying). The content of plane presented in analogue form on the cadastral plans in different scale, what you can see on Table no.1. Since founding, to this day by the cadastral survey on cadastral municipalities was carried out in accordance with municipality possibility and financial capabilities, plans and requirements or needs of the public administration. In the municipality of Bačka Palanka primary survey conducted in the period since 1864. to 1900 . in scale 1:2880, in stereographic projection. The new survey was conducted in 1967. until 1970., in the cadastral municipality of Bačka Palanka-town, in GaussKruger projection, using aerial surveying, and the period of 1967-1991, in the some cadastral municipalities, a new survey is done in the process of redistribution of agricultural land. In the period from 1966 to 1967, in the town area, there were defined and stabilized the points of town polygonal network I and II order, which used for this surveying. At that, time in the city polygonal network of the first order determined 204, and in the network of second order 131 point, was determined. For the purposes of the construction of building area municipality of Bačka Palanka, in 2000, it was developed polygonal network first rank on the field with 202 points, which relied on eight points of reference network of the Republic of Serbia. In addition, for the survey of cadastral municipality Bačka Palanka - town in altitude view, from the $1966^{\text {th }}-1967$, it was stabilized the specific town leveling networks with points first and second order. Back then, in the city, leveling network of first order it was determined 12 benchmarks, and in the network second order it was determined 51 benchmarks.

Based on survey data, survey and restoration, in the past and applying contemporary technological solutions, it worked out of digital cadastral maps. In the municipality of Bačak Palanka made digital cadastral maps (DCM) in seven of cadastral municipalities, Mladenovo, Nova Palanka, Obrovac, Parage, Pivnice, Silbaš and Čelarevo. 
Table 1: Overview of cadastral plans by CM and theirs scales on the territory of the municipality Bačka Palanka [02]

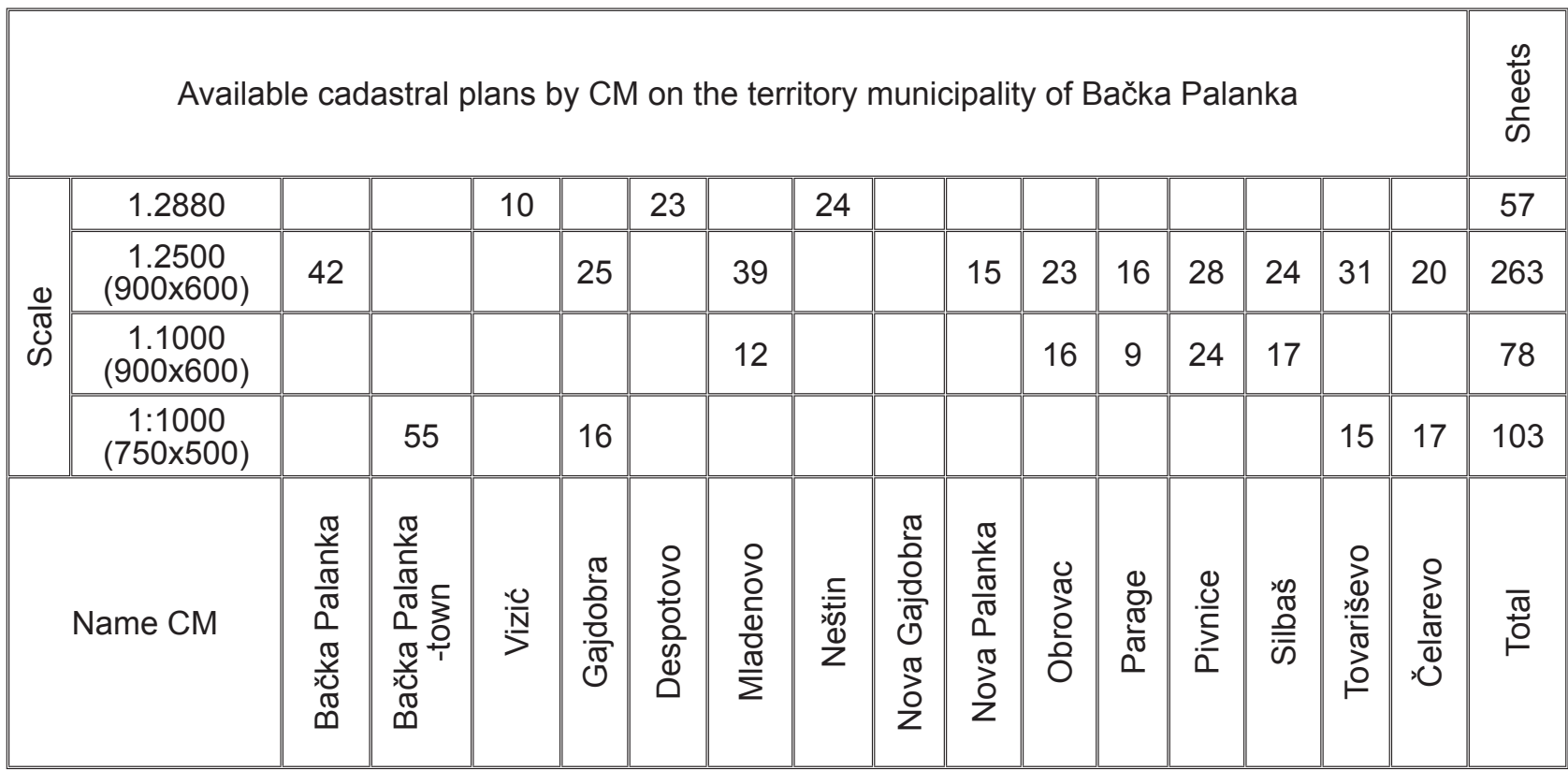

In accordance with the legislation and the tendency of regulation of this area and in the municipality of Bačka Palanka are derived works to create a unique cadastral records and real estate cadastre. From the 15 cadastral municipalities which existing on territory of Bačka Palanka, in mentioned these seven $\mathrm{CM}$ which are made of DCP, for another 3 CM, Bačka Palanka, Gajdobra and Tovriševo are made the cadastre of real estate, while for the remaining $5 \mathrm{CM}$ there is the land cadastre and land registration (lend book). During 2003 year, The Government of the Republic of Serbia (SG RS no. 93/2003), on the base of the decision of Backa Palanka municipality and the recommendation of RGA, decided to change the boundaries of CM Bačka Palanka - city. For once, this CM is incorporated parts of CM Bačka Palanka and New Palanka, in order to extend area of urban construction land in the municipality.

The level of efficiency of existing cadastral plans can the best be seen by direct comparison by simultaneous observation of the existing building line display on the cadastral plan and built a new aerial photography (e.g. scanned cadastral maps and digital aerial photo or, better, digital ortophoto), the same area, which automatically indicates the existence of newly constructions, roads, etc.. or other elements that are not recorded on cadastral maps and other documents. This fact undoubtedly contributes to the visual character of the need of solving the issue of ille- gal construction or legalization or implementation process of collection of fees for the use of lend or for consolidation of urban construction lend. By simply superimposing i.e. simultaneous looking available cadastral maps and a newly constructed digital ortophoto of the same part of the territory, we concluded that the level of detail on updating cadastral maps. The result can be seen from the attached pictures and considerable the table. Wider area of building engagement area of Bačka Palanka municipality (for which there is a digital ortophoto) extends to 70 sheets of scale 1:1000 (format $900 \times 600 \mathrm{~mm}$ ).

In the following examples, clearly, there is a difference between the situations of having registered / available cadastral maps and the current situation on the ground i.e. from the summer of 2010th when the aerial photographing was recording. On the lower images are examples of these differences for the parts of Sava Kovačević Street and Liberation Square in Bačka Palanka.

Direct observation and counting of objects displayed on cadastral maps and objects that exist in the field, it is evident that the percentage of unregistered facilities ranging up to $40 \%$ in some parts of the building regions. This inevitably suggests that it is necessary to undertake all planning activities to overcome this situation, i.e. carried out survey and register of all buildings and other elements that make the real estate registry. 


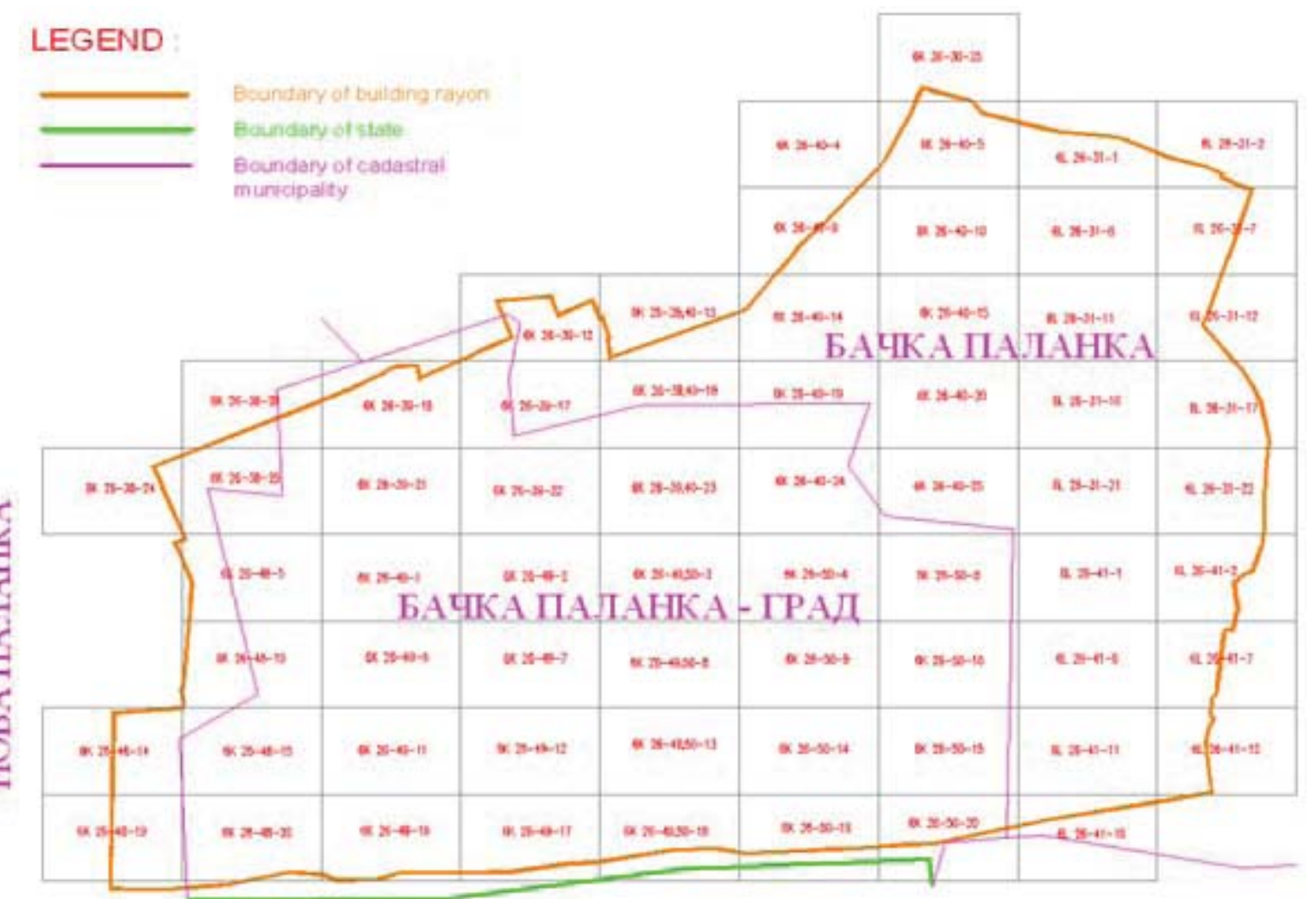

\section{CROATIA REPUBLIC}

Figure 3: Overview drawing sheets of digital ortophoto in the scale 1:1000 which cover building region of the town Bačka Palanka [02]

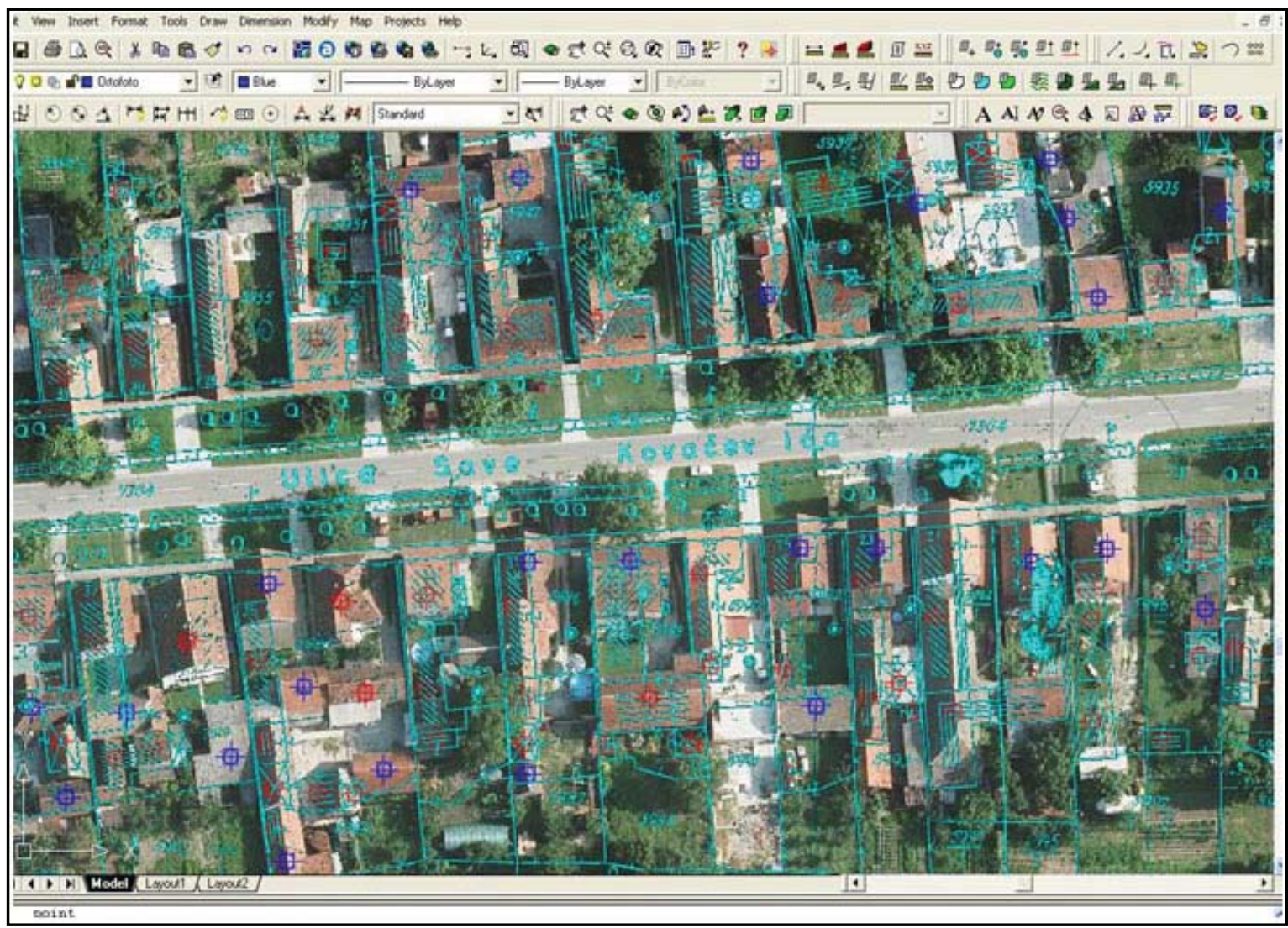

Figure 4: Comparison of the displayed objects on the cadastral plot (red) and the existing buildings on the ground / new digital ortophoto (blue); at the part of the Sava Kovačević street in Bačka Palanka 


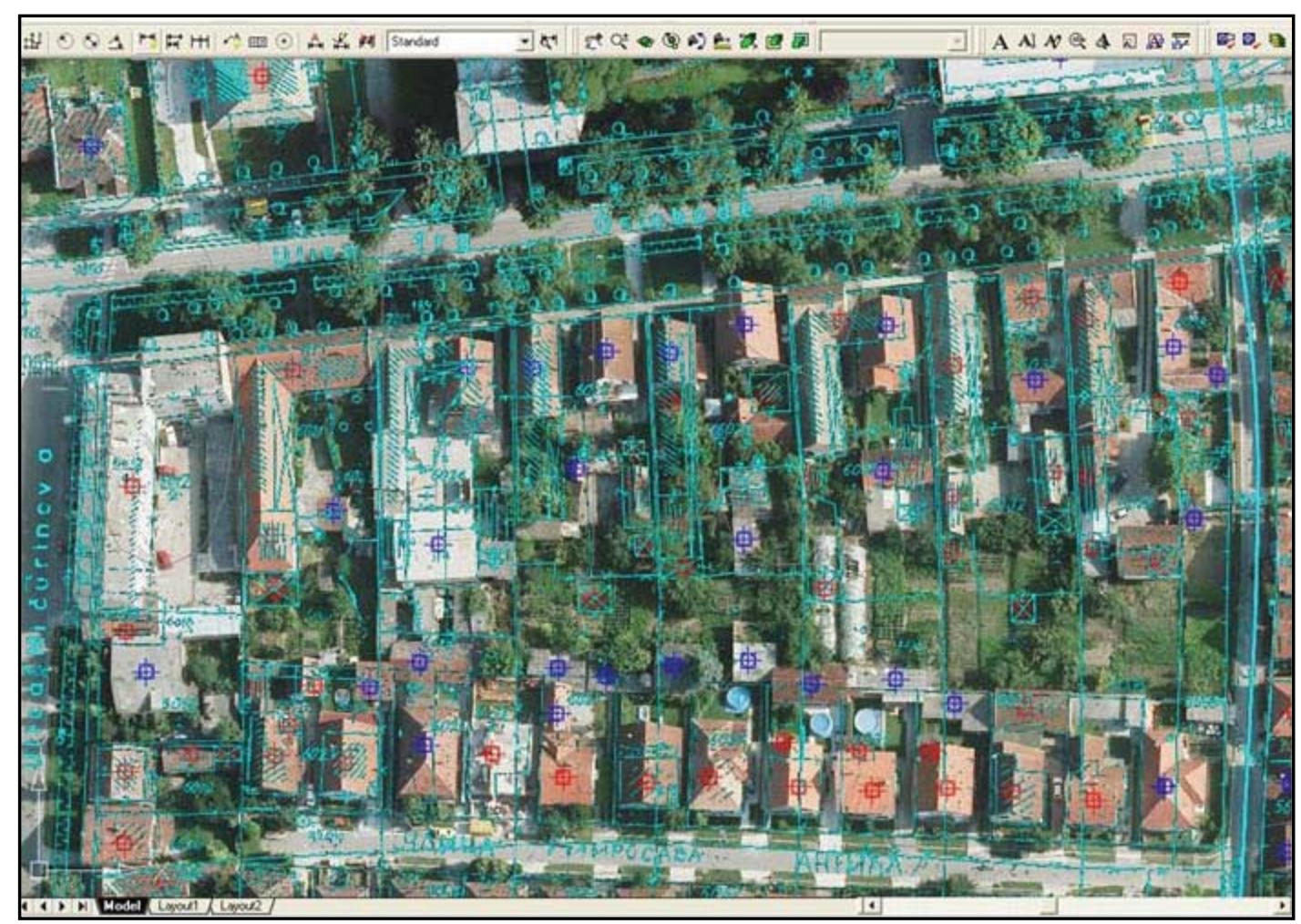

Figure 5: Comparison of the displayed objects on the cadastral plot (red) and the existing buildings on the ground / new digital ortophoto (blue); at the part of the Liberty place in Bačka Palanka

Table 2: Summary of existing and newly built structures in the building zone on the territory of three cadastral municipalities in Municipality of Bačka Palanka [02]

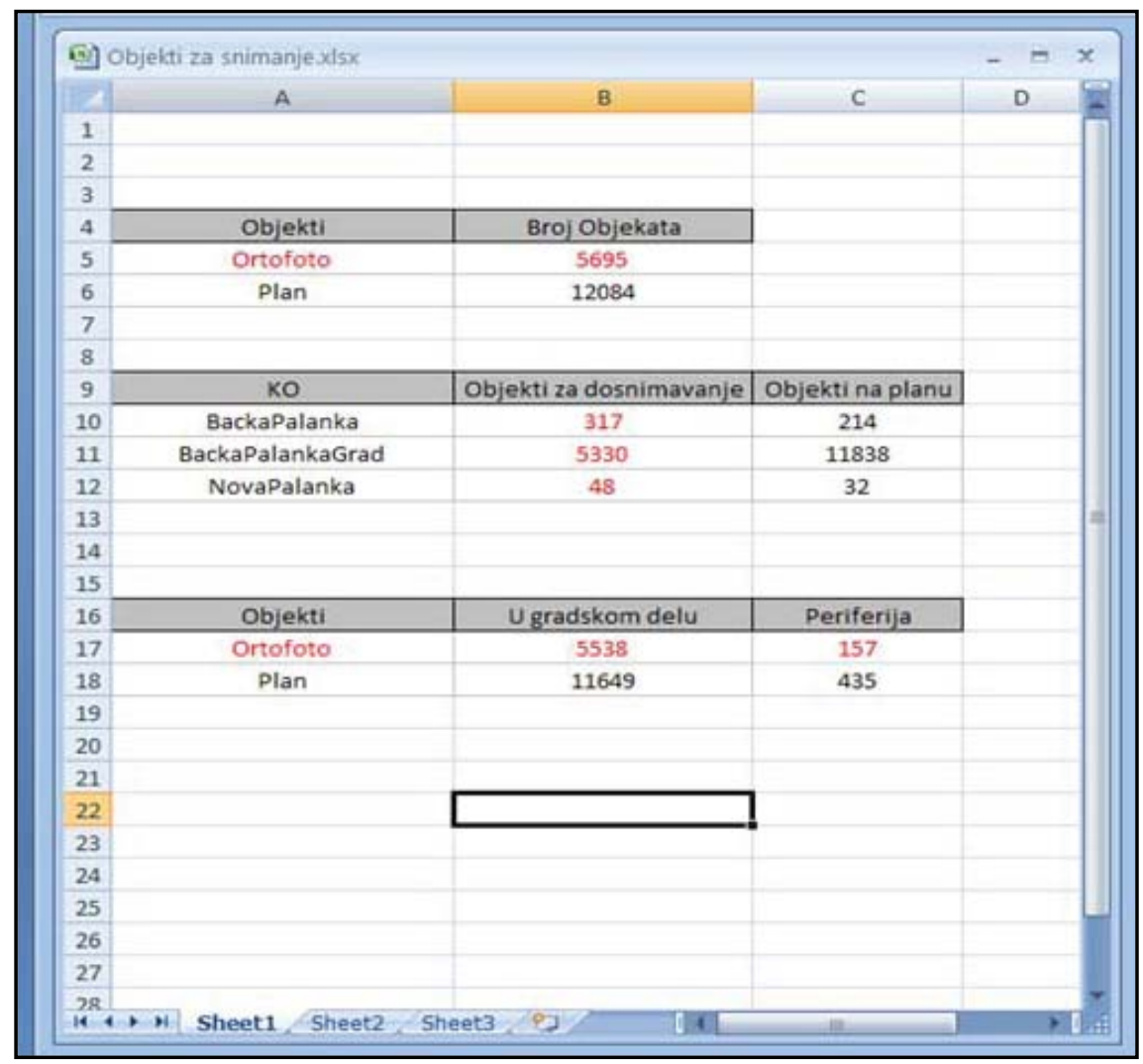

From the review table is evident that in the building zone it will be necessary to do additional sur-

veying on more than about 5700 new objects, yet. 


\section{RENOVATION NEEDS OF THE STATE SURVEY AND CREATION OF ESTATE CADASTRE}

On the territory of CM Bačka Palanka - town maintenance of cadastral surveying was carried out by "modify" measurements. Since 2000, the maintenance and changes in surveying measured by geodetic instruments from the existence geodetic network and using polar method of surveying. During the mapping we observed discrepancies - one objects or their parts "fell" into the adjacent parcel and if it is not the case in the field (errors are sometimes up to $2 \mathrm{~m}$ ). Based on previous survey data it was established the land register (book) with a new numbering of land parcels from the land cadastre. These jobs usually completed until 1982, but not fully completed. Disagreement over the land register is about $40 \%$. In the land cadastre are registered holders of tenure for fiscal necessity, but in the Land Registry are registered holders of title to the scope of law - all co-owners. Maintenance of operate cadastral land is carried out in the software "JS", version 7.1.

Besides the foregoing, it is certain that the existence of disagreement survey and cadastral with the situation on the ground, like some roadspublic areas and in particular, analyzing only the objects on the ground are about $50 \%$ changed / increased relative to the state evidence and it cannot be eliminated routine maintenance measures. For example, town traffic roads on the plans exist only as cadastral parcels, but not as a actual objects carried out of the situation. There are no data in the cadastral records of parts of the floors of buildings. So the tax is charged only for agricultural land by the state land cadastre evidence, and property tax is charged only after user presented oneself - the owner of construction (because only when you establish real estate cadastre it will be possible for all owners pay property tax according to the actual records and adequate accounting).

Therefore, on the part of the area with the status of urban construction land (formed of cadastral municipalities Bačka Palanka- town with old borders area which has 1443 hectares, and annexed parts of CM Bačka Palanka, measuring 100 hectares and CM Nova Palanka area of 236 hectares, for a total of 1779 hectares would be required do the following:
- Accomplish a renovation of cadastral surveying by modern methods and make the establishment of real estate cadastre (the complete procedure of collecting spatial data on estates and related rights, the creation of appropriate databases, and to put on public display of data of estates and rights to them - to establish a unique record database cadastre - in accordance with the performed pre-main project renewal survey and establish real estate cadastre);

- Develop a database of digital cadastral map based on numerical data renewal survey;

- Put in practice the establishment of real estate cadastre (database).

Looking at legislation in this area and technology process, reconstruction activities of the state survey and real estate cadastre would be conducted in accordance with this, i.e.:

1. Medium-term programs of works of the government would be bringing based on the proposal of RGA, while the annual work plan prepared RGA;

2. The decision on the renewal survey and real estate cadastre would bring the Government of Serbia, based on proposals RGA, for the area where there is disagreement survey and documentation with the situation on the ground, but which cannot be cured out by measures of routine maintenance;

3. Financial support for realization of programs and work plans are funded from nation budget of RS, the local government, from donations and from the interested legal and natural persons;

4. Preliminary and Main design creating RGA or geodetic organizations, upon request and under terms of reference investor, but a listed projects are subject to professional or technical control carried out by the revision commission of RGA op Geodetic organization wich accomplished all the legal requirements;

5. Accomplishment geodetic work performing contractor who accomplish all conditions and who selected by the investor in accordance with the law;

6. Professional supervision executing RGA;

7. Receiving, verification and certification of final documentation executing RGA by itself resolution; 
8. Thus founded the real estate cadastre would apply from the day of receipt of the RGA and after submitting in the relevant department of cadastre for further protection, storage, use and maintenance.

If we kook the territory of the Municipality Bačka Palanka with all features, it has elements which significantly contribute to easier performance process of geodetic measurement, such as the flat terrain, developed traffic infrastructure, arable land, dense settlements and settlements are near the road and so on. All these elements significantly might decrease the overall costs of the works, and above all for field surveying work.

In analyzing the present situation, it is evident that already existed decisions of the Municipality Bačka Palanka on the renewal survey and implementation of the lend consolidation of appropriate cadastral municipalities where by the design solutions proposed the selected method of measurement and reconstruction of the cadastre of real estate. It indicates that there is a strong preference of citizens and local governments for these activities to finish it as soon as possible. The completing of it bring significant advantages estate enlargement (parcels), arranging travel and drainage network, land use, collection of adequate fees, etc.., and also it provides update, accurate and modern picture of regulation of real estate cadastre and space in general, as the basis for a quality work of local self-government.

\section{CONCLUSION}

In the municipality of Bačka Palanka, in the territory with the status of urban construction land, i.e. the territory of the CM Bačka Palanka - town, there is a disagreement of data of cadastral surveying with the situation on the ground. For example, the roads - public areas, and facilities where there has been a change for $50 \%$, compared to the situation in the evidence. It is certain that this situation cannot be eliminated routine maintenance measures, and this situation inevitably slows down a series of activities of municipal bodies, which depend and using the real estate cadastre data.

The main activities in this field, in accordance with the competence, are starting from the Republic Geodetic Authority. RGA prepares and proposes a decision for the renewal of surveying and cadastre, but the same bringing by the Government of the Republic of Serbia and the As- sembly of the Municipality Bačka Palanka, as a local government. In addition, the decisions are bringing regarding to the financing of the works. For the final realization of the mentioned surveying, with considering the volume of those works and as well as important financial amount for that, it is necessary that the Republic Geodetic Authority, together with the Assembly of the Municipality Bačka Palanka set priorities and hierarchy of implementation, as well as the dynamics of total project by cadastral municipalities.

Then it is necessary to make design and certify main project for every cadastral municipality and technical documentation. Based on that, it will be start technical implementation using appropriate methods in the process of collecting and processing data on real estate cadastre data, and rights on them. It going up to produce adequate data bases, process of public display of data on immovable property and rights to them, and their establishment and use in the service for real estate cadastre data in municipality. The whole process requires high quality and constant cooperation corresponding participants such as the Republic Geodetic Authority, a body of local self-government and surveying organization, which will be including in the implementation of this project.

\section{REFERENCES}

1) Kuburić M., Lero M. (2011): Surveying works in road designing and construction, Journal of Applied Engineering Science (Istraživanja i projektovanja za privredu), Vol. 9, No. 3, pp 393-400.

2) Law on State Survey and Real Estate Cadastre (Official Gazette of RS, No. 79/09 and 18/10)

3) Official presentation / website of the municipality of Bačka Palanka, www.backapalanka.rs

4) Previous studies justification of cadastral survey of Bačka Palanka municipality, GEOPUT doo, Belgrade,2010.

5) The Republic Geodetic Authority, territorial organization, the status of real estate cadastre per Municipalities, contact information, the official website of the Authority, www.rgz.gov.rs

Paper sent to revision: 07.05.2013.

Paper ready for publication: 28.08.2013. 